\title{
The mechanism of thermal decomposition of oxidized nickel ore from the Kulikovskoye deposit in air
}

\author{
(C) Alfred N.Gabdullin, ${ }^{1,2}{ }^{+}$Evgenia A. Nikonenko, ${ }^{1}$ Timofey M. Klyuev, ${ }^{1}$ \\ Irina S. Alyamovskaya ${ }^{1}$, and Vyacheslav F. Markov ${ }^{1,3}$ \\ ${ }^{1}$ Ural Federal University Named after the First President of Russia B.N. Yeltsin. Mira St., 19. \\ Ekaterinburg, 620002. Sverdlovsk Region.Russia.Phone: +7 (343)375-45-68.E-mail: gan1105@mail.ru \\ ${ }^{2}$ Department of metallurgy UMMC Technical University. Pr. Uspensky, 3. Verkhnyaya Pyshma, 624091. \\ Sverdlovsk region. Russia. Phone: +7 (34368) 78-310. \\ ${ }^{3}$ Ural institute State Fire Service of EMERCOM of Russia. Mira St., 22. Ekaterinburg, 620002. Russia. \\ Phone: +7 (343) 360-81-68.
}

\begin{abstract}
${ }^{*}$ Supervising author; ${ }^{+}$Corresponding author
Keywords: hydrometallurgy, nickel ores, IR spectroscopy, Raman spectroscopy, X-ray phase analysis, thermographic analysis.
\end{abstract}

\begin{abstract}
The object of the research is oxidized nickel ores from the Kulikovskoye deposit (Southern Urals) - nonconforming nickel-containing raw materials. The work is devoted to the study of chemical and phase composition to substantiate the choice of the method of processing this material in order to obtain valuable inorganic substances in demand in the chemical and metallurgical industries: oxide and (or) magnesium nitrate, iron and nickel containing concentrates, silicon dioxide. The chemical composition of ore demonstrating the feasibility of developing a technology for its complex processing is presented. X-ray phase analysis showed the presence of silicates of the serpentine group (lizardite-1M and lizardite-1T) and the group of spinelids (magnesioferrite) in the oxidized nickel ores of the Kulikovskoye deposit. A literary analysis suggested the presence of other hydrosilicates (antigorite, chrysotile, nimite, talc, revdinskite, clinochlore, etc.). IR spectroscopic analysis was performed to confirm the phase composition. A thermogravimetric analysis was performed, which makes it possible to determine the conditions for the preliminary preparation of ground raw materials. To determine the mechanism of thermal decomposition of ore in air, intermediate products were obtained at temperatures of 600,700 and $900{ }^{\circ} \mathrm{C}$. According to X-ray diffraction, IR and Raman spectroscopic analyzes, at $600{ }^{\circ} \mathrm{C}$, the removal of $\mathrm{OH}$ groups, water molecules and the destruction of the crystal lattices that make up the mineral ore with the formation of oxides $\left(\mathrm{FeO}, \mathrm{SiO}_{2}, \mathrm{MgO}\right)$ begins. At $700{ }^{\circ} \mathrm{C}$, island silicates are formed: forsterite $\mathrm{Mg}_{2} \mathrm{SiO}_{4}$, larnite $\mathrm{Ca}_{2} \mathrm{SiO}_{4}$. At $900{ }^{\circ} \mathrm{C}$, the interaction between silicates continues with the complication of the composition of functional groups. Based on the described properties of minerals and previous work on the hydrometallurgical technology of processing oxidized nickel ores and metal-containing silicate raw materials in order to obtain inorganic substances, nitric acid is proposed as a leaching agent.
\end{abstract}

\section{References}

[1] A.A. Tseidler. Metallurgy of nickel. GNTI literature on ferrous metallurgy. 1947. 134p. (russian)

[2] A.A. Chunarev, O.B. Kolmachikhina, S.S. Naboichenko. A review of methods for the processing of oxidized nickel ores and prospects for the development of nickel production in the Urals. Ural Industrial. Bakunin's readings: Industrial modernization of the Urals in the XVIII-XXI centuries XII All-Russian Scientific Conference dedicated to the 90th anniversary of the Honored Scientist of Russia, Doctor of Historical Sciences, Professor Alexander Vasilievich Bakunin. Materials Yekaterinburg, December 4-5, 2014: in 2 tons. Yekaterinburg: UrFU. 2014. Vol.2. P.333-335. (russian)

[3] B.D. Khalezov, O.V. Zayakin, A.S. Gavrilov, and V.I. Zhuchkov. Hydro-, pyrometallurgical method of obtaining alloys system Fe-Ni-Cr-Mn-Si. Butlerov Communications. 2017. Vol.52. No.10. P.111-117. DOI: $10.37952 /$ ROI-jbc-01/17-52-10-111

[4] L.N. Nazharova. Hydrochloric acid processing of serpentinite: Author's abstract. dis. Cand. tech. sciences. Kazan. 1999. 16p. (russian)

[5] Pat. 2097322 RF IPC6 S01B33/142. Method for complex processing of serpentinite. V.V. Velinsky, G.M. Gusev; applicant and patentee V.V. Velinsky, G.M. Gusev. №5028576/25; appl. 02.24.1992; publ. 11/27/1997. Bul №5/2002. (russian) 
THE MECHANISM OF THERMAL DECOMPOSITION OF OXIDIZED NICKEL ORE FROM THE KULIKOVSKOYE... 118-126

[6] A.S. Molodykh, V.V. Vaitner, E.A. Nikonenko, A.N. Gabdullin, and S.F. Katyshev. A method of producing nickel concentrate from Serov's nickel ore deposit. Butlerov Communications. 2016. Vol.47. No.9. P.67-72. DOI: 10.37952/ROI-jbc-01/16-47-9-67

[7] Pat. 2292300 RF IPC C01F5/02. Method for processing of serpentinite: Kalinichenko I.I., Gabdullin A.N.; the applicant and the patent owner I.I. Kalinichenko; № 2005122242/15; appl. 13.07.2005; publ. 27.01.2007. Bull. No.3. P.10. (russian)

[8] A.N. Gabdullin, E.A. Nikonenko, T.M. Klyuev, and V.F. Markov. Chemical and phase composition of oxidized nickel ores of the Kulikovsky deposit - raw materials for the production of magnesium compounds, Fe-Ni-containing concentrates, $\mathrm{SiO}_{2}$. Butlerov Communications. 2018. Vol.55. No.8. P.156161. DOI: 10.37952/ROI-jbc-01/18-55-8-156

[9] L.G. Ananyeva. Mineralogy. Silicate class: study guide. National Research Tomsk Polytechnic University. Tomsk: Publishing House of Tomsk Polytechnic University. 2011. 77p. (russian)

[10] http://www.himikatus.ru/art/newpow/silikaty6.php / the site "Himikatus.ru. Chemical portal", 2019 (the date of circulation 14.04.2019). (russian)

[11] K.V. Kozhemyako, V.I. Matyukhin, M.A. Mikheenkov. Development of technological bases for the processing of slag from copper smelting. Heat Engineering and Computer Science in education, science and production (TIM-2015). Collection of reports IV All-Russian scientific-practical conference of students, graduate students and young scientists with international participation, dedicated to the 95th anniversary of the department and the university. Ministry of Education and Science of the Russian Federation, Ural Federal University named after the first President of Russia BN Yeltsin. 2015.

Publisher: Ural Federal University named after the first President of Russia B.N. Yeltsin, Yekaterinburg. 2015. P.48-52. (russian)

[12] V.P. Ivanova. Thermal analysis of minerals and rocks. Leningrad: Nedra. 1974. 399p. (russian)

[13] I.I. Plusnina. Infrared spectra of minerals. Moscow: Publishing House of Moscow University. 1976. 175p. (russian)

[14] K. Nakamoto. IR spectra and Raman spectra of inorganic and coordination compounds. Moscow: Mir. 1991. 536p. (russian) 